\title{
Hemoglobin Disorders in South India
}

\author{
Vani Chandrashekar and Mamta Soni \\ Department of Hematology, Apollo Hospitals, 21, Greams Lane, Off Greams Road, Chennai 600006, India
}

Correspondence should be addressed to Vani Chandrashekar, drvani001@gmail.com

and Mamta Soni,drmamta_s@apollohospitals.com

Received 12 March 2011; Accepted 2 May 2011

Academic Editors: J. S. Gibson, C. Panizo, A. G. Tsai, and C. A. White

Copyright (C) 2011 V. Chandrashekar and M. Soni. This is an open access article distributed under the Creative Commons Attribution License, which permits unrestricted use, distribution, and reproduction in any medium, provided the original work is properly cited.

\begin{abstract}
Cation exchange-high performance liquid chromatography (CE-HPLC) is increasingly being used as a first line of investigation for hemoglobinopathies and thalassemias. Together with a complete blood count, the CE-HPLC is effective in categorizing hemoglobinopathies as traits, homozygous disorders and compound heterozygous disorders. We carried out a one year study in Apollo Hospitals, Chennai (Tamil Nadu, South India) during which 543 abnormal chromatogram patterns were seen. The commonest disorder we encountered was $\beta$-thalassemia trait $(37.9 \%)$, followed by HbE trait (23.2\%), homozygous HbE disease (18.9\%), $\mathrm{HbS}$ trait (5.3\%), $\mathrm{HbE} \beta$-thalassemia (4.6\%), $\mathrm{HbS} \beta$-thalassemia (2.5\%), $\beta$-thalassemia major $(2.3 \%), \mathrm{HbH}(1.6 \%)$, homozygous $\mathrm{HbS}(1.4 \%), \mathrm{HbD}$ trait $(0.7 \%)$. The average value of $\mathrm{HbA} 2$ in $\beta$-thalassemia minor was $5.4 \%$. $\beta$-thalassemia major had an average $\mathrm{HbF}$ of $88 \%$ and in $\mathrm{HbH}$ the mean $\mathrm{A} 2$ was $1.4 \%$. Among the $\mathrm{HbE}$ disorders the $\mathrm{HbA} 2+\mathrm{HbE}$ was $30.1 \%$ in the heterozygous state, $90.8 \%$ in the homozygous state and $54.8 \%$ in $\mathrm{HbE} \beta$-thalassemia. In the sickle cell disorders, HbS varied from $30.9 \%$ in the trait to $79.9 \%$ in the homozygous state to $65.6 \%$ in $\mathrm{HbS} \beta$-thalassemia.
\end{abstract}

\section{Introduction}

Hemoglobinopathies result from a structural defect in the globin gene, whereas the thalassemias are due to a quantitative defect in the globin chain production. The average frequency of $\mathrm{HbS}$ and $\mathrm{HbD}$ is $4.3 \%$ and $0.86 \%$, respectively in Indian population [1]. $\mathrm{HbS}, \mathrm{HbE}$, and $\mathrm{HbD}$ are prevalent in India [1]. HbE gene frequency in north eastern regions of India has been reported to be $10.9 \%$ [1]. In a study, the prevalence of sickle cell disorders was found to vary from $2.4 \%$ to $5.6 \%$ among the tribes of Orissa in eastern India [2]. In central India, the prevalence of sickle cell disorders was observed to be $5.7 \%$ among children [3]. The frequency of $\mathrm{HbD}$ is around $0.5-3.1 \%$ in Uttar Pradesh [4].

Hemoglobin separates into major and minor hemoglobins when subjected to CE-HPLC. The order of elution of the various components is HbAla, HbAlb, HbF, LA1c/CHb-1, LA1c/CHb-2, HbAlc, P3 (Hbd component), $\mathrm{HbA}$, and HbA2. The minor hemoglobins Ala, A1b, A1c, F1, and the P3 component are posttranslational modifications of the globin chains. HbA2, a minor hemoglobin, however, is composed of two alpha and two delta chains.
$\mathrm{HbA0}$ and $\mathrm{HbF}$ are the major hemoglobins in a normal hemolysate.

An elevated $\mathrm{HbA} 2$ with an average value of about $5 \%$, along with microcytic hypochromic indices, is characteristic of $\beta$-thalassemia trait [5]. In $\beta$-thalassemia major, in addition to a markedly microcytic hypochromic blood picture, there are elevated $\mathrm{HbA} 2$ and elevated $\mathrm{HbF}$ ranging from 10 to $90 \%$ [5]. HbE trait is diagnosed by the presence of a high $\mathrm{HbA} 2$ (E+A2), approximately 30\% [6]. Homozygous HbE patients have approximately $90 \% \mathrm{HbE}+\mathrm{A} 2$ with minor elevation of $\mathrm{HbF}$ [6]. $\mathrm{HbE}+\mathrm{A} 2$ levels of $40-60 \%$ with marked elevation of $\mathrm{HbF}$ are seen in $\mathrm{HbE}-\beta$-thalassemias [6]. $\mathrm{HbS}$ is around $40 \%$ in sickle cell trait, $90-95 \%$ in sickle cell anemias (which varies inversely with $\mathrm{HbF}$ proportion), and less than $50 \%$ in sickle $\beta$-thalassemias [7]. Approximately less than $50 \%$ of abnormal hemoglobin is seen in HbD traits [7].

The present study highlights the detection of the hemoglobinopathies and thalassemias by CE-HPLC. We undertook this study as there is limited available data on large scale studies of hemoglobinopathies in South India. Large studies on the spectrum of hemoglobinopathies on the Bio-Rad D-10 analyser have not been reported previously. This 
TABle 1: Distribution of hemoglobin disorders in adults and children.

\begin{tabular}{lcc}
\hline Disorder & 12 years and less $(\%)$ & More than 12 years $(\%)$ \\
\hline$\beta$-thalassemia trait & 4.7 & 35 \\
HbE trait & 3.6 & 19.5 \\
Homozygous HbE & 2.3 & 16.5 \\
HbS trait & 0.7 & 4.6 \\
HbE $\beta$-thalassemia & 1.8 & 2.7 \\
HbS $\beta$-thalassemia & 0.7 & 1.8 \\
$\beta$-thalassemia major & 2.3 & - \\
\hline
\end{tabular}

study is a one-year study, carried out in Apollo Hospitals, Chennai, a tertiary care hospital in South India, and includes all patients who had a clinical or familial suspicion of hemoglobinopathy and a hemoglobinopathy work up was ordered for diagnostic purposes.

\section{Materials and Methods}

All patients for whom a CE-HPLC was requested during the period from December 2009 to November 2010 were included in this study. Patients with a recent history of transfusion (three months prior to sample collection) were excluded from the study. A complete blood count (LH-750 analyzer) for red cell indices, a peripheral smear for red blood cell morphology, and an $\mathrm{HbH}$ preparation for $\mathrm{HbH}$ inclusions were studied for all the patients. $\mathrm{HbH}$ smear was prepared by incubating equal volume of blood with new methylene blue for two hours at $37^{\circ} \mathrm{C}$ and then preparing a smear similar to that for reticulocyte count. $\mathrm{HbH}$ inclusions ("golf ball" inclusions) are seen as numerous, large pale blue inclusions distributed evenly in the red cells. A sickling test using the reducing agent sodium metabisulfite was prepared for cases with an abnormal hemoglobin in the $\mathrm{S}$ window of the chromatogram. The blood samples collected in EDTA vacutainer were diluted and injected in to the analytical cartridge of D-10 analyzer (Bio-Rad Laboratories, Hercules, CA). Phosphate buffers of increasing strength are then pumped in to the cartridge and the hemoglobins elute out based on their ionic interactions with the cartridge. The elute flows through the flow cell of the filter photometer where their absorbance at $415 \mathrm{~nm}$ is recorded. A chromatogram for each sample is obtained using the $\mathrm{HbA} 2 / \mathrm{HbF} / \mathrm{HbA} 1 \mathrm{c}$ dual program. A recorder pack containing the elution buffers, calibrators, calibrator diluents, whole blood primer, and sample vials are provided with each kit. The hemoglobins fall into windows which are defined by their retention times. Hemoglobins with retention times outside the windows are detected as unknown peaks. The reference ranges for $\mathrm{HbA} 2$ and $\mathrm{HbF}$ in our laboratory for adults are $1.8-4 \%$ and less than 1 , respectively.

\section{Observations}

There were five hundred and forty three abnormal chromatograms (see Figures 1, 2, 3, 4, 5, and 6). Of these, 206

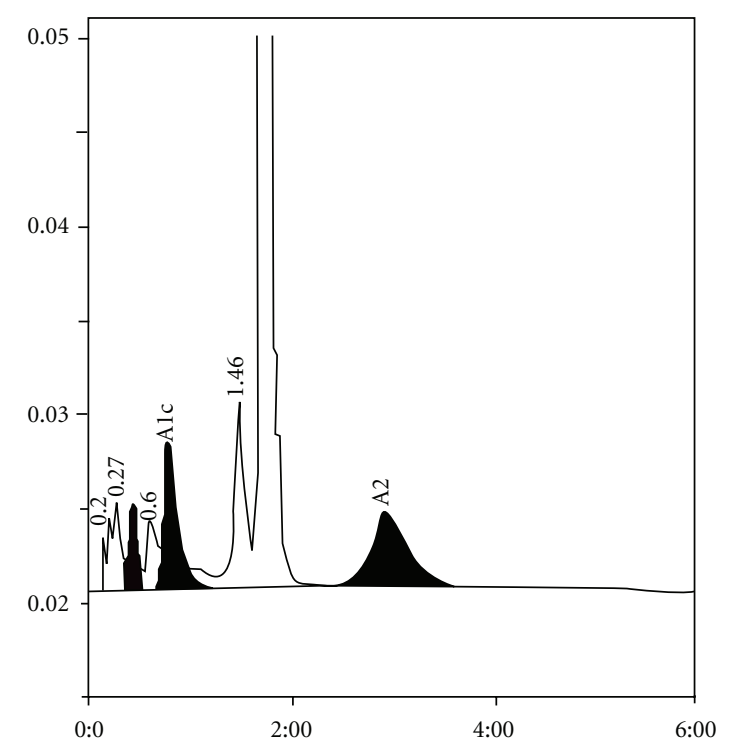

Figure 1: $\beta$-thalassemia trait with $\mathrm{HbA} 2$ of 5.6 and $\mathrm{HbF}$ of $1.2 \%$.

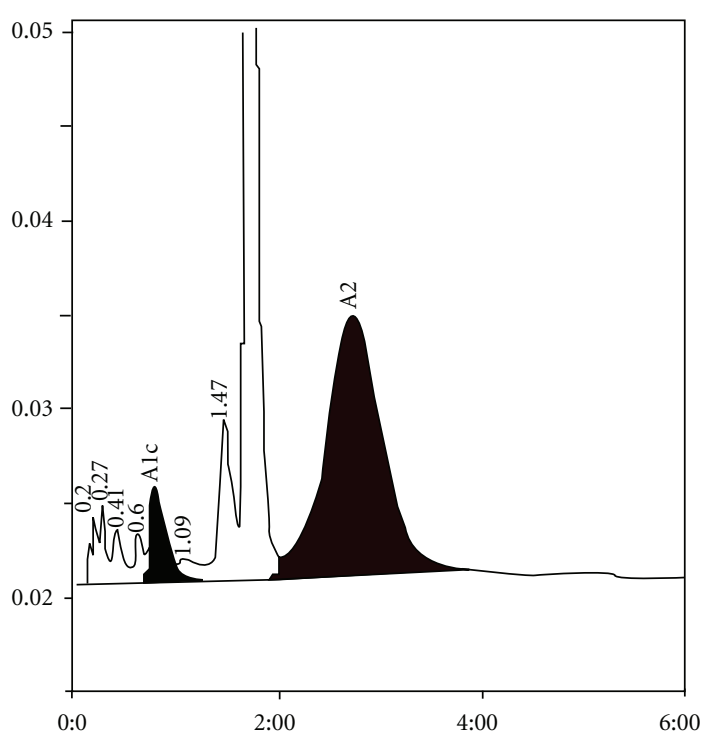

Figure 2: $\mathrm{HbE}$ trait with $\mathrm{HbA} 2$ and $\mathrm{HbE}$ in the same window and $\mathrm{HbE}+\mathrm{A} 2$ amounting to $31.7 \%$.

(37.9\%) were $\beta$-thalassemia trait, $126(23.2 \%) \mathrm{HbE}$ trait, 103 (18.9\%) homozygous HbE, 29 (5.3\%) HbS trait, 25 (4.6\%) HbE $\beta$-thalassemia, 14 (2.5\%) HbS $\beta$-thalassemia, $13(2.3 \%) \beta$-thalassemia major, nine (1.6\%) $\mathrm{HbH}$, eight (1.4\%) homozygous HbS, four (0.7\%) HbD trait, one $(0.1 \%)$ each of homozygous $\mathrm{HbD}$ disorder, $\mathrm{HbJ}$ trait, HbLepore trait, hereditary persistence of fetal hemoglobin, and HbSC and HbSE disorder. Of these, 289 (53.2\%) were males and (46.7\%) 254 females. Table 1 shows the distribution of the common hemoglobin disorders among children and adults in our study. Among our patients, $16.5 \%$ were less than 12 years and in both groups $\beta$-thalassemia trait was the commonest abnormality. 


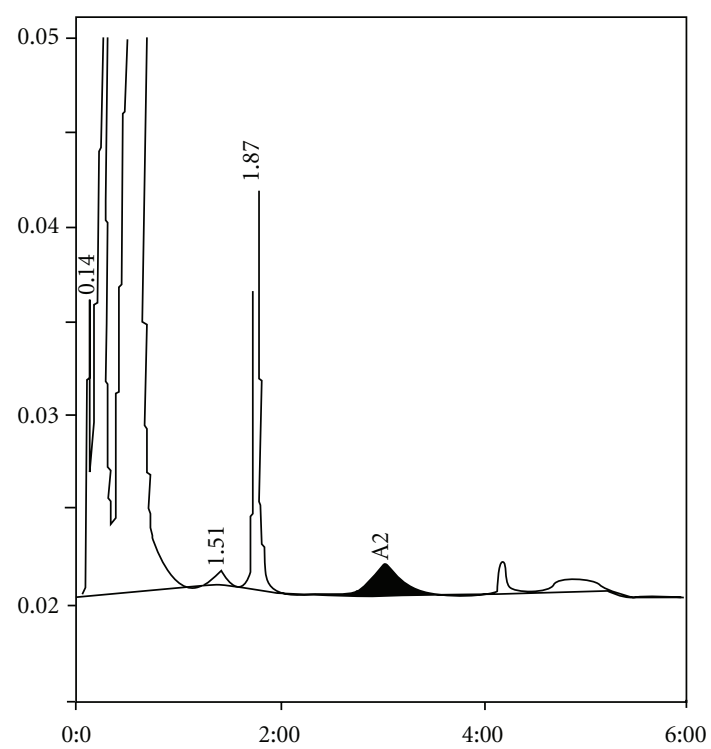

Figure 3: $\beta$-thalassemia major with elevated $\mathrm{HbF}$.

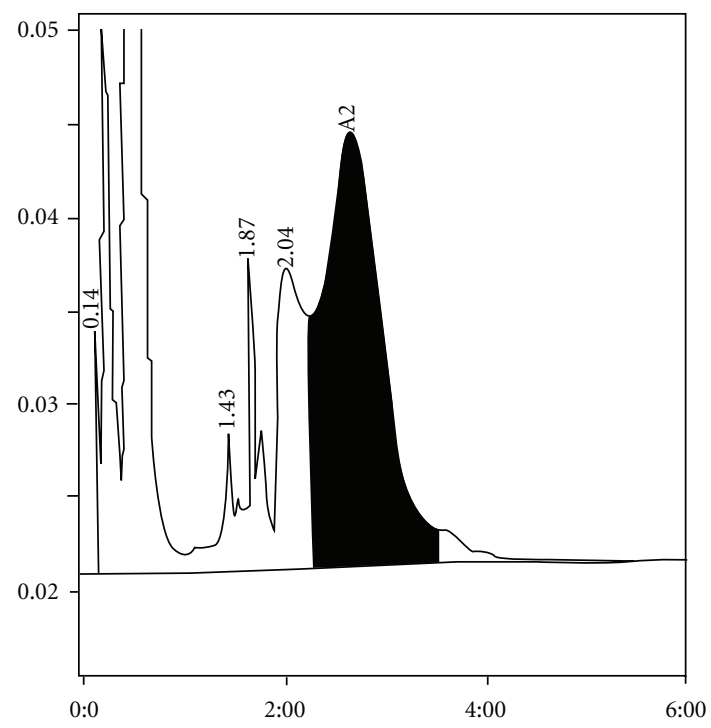

FIgURE 4: $\mathrm{HbE} \beta$-thalassemia with elevated $\mathrm{HbF}$ falling in the LA1c/CHb-1 peak. $\mathrm{HbE}+\mathrm{A} 2$ was $41.6 \%$ and $\mathrm{HbF} 35.7 \%$.

3.1. Heterozygous Hemoglobinopathies (E, S, D Traits). The lowest average hemoglobin was seen in $\mathrm{HbD}$ trait. The lowest average $\mathrm{MCV}, \mathrm{MCH}$, and $\mathrm{MCHC}$ was seen in $\mathrm{HbE}$ trait. The highest percentage of abnormal hemoglobin was seen in $\mathrm{HbD}$ trait (Table 2). The single case of J trait had a P3 peak of $22.5 \%$ (HbJ presents as an elevated $\mathrm{P} 3$ peak).

3.2. Compound Heterozygous Disorders ( $E \beta$-Thalassemia and $S \beta$-Thalassemia). The lowest average hemoglobin, MCV, $\mathrm{MCH}$, and $\mathrm{MCHC}$ were seen in HbE Beta-thalassemia. The average abnormal hemoglobin was more in $\mathrm{HbS} \beta$ thalassemia compared to $\mathrm{HbE} \beta$-thalassemias (65.6 versus

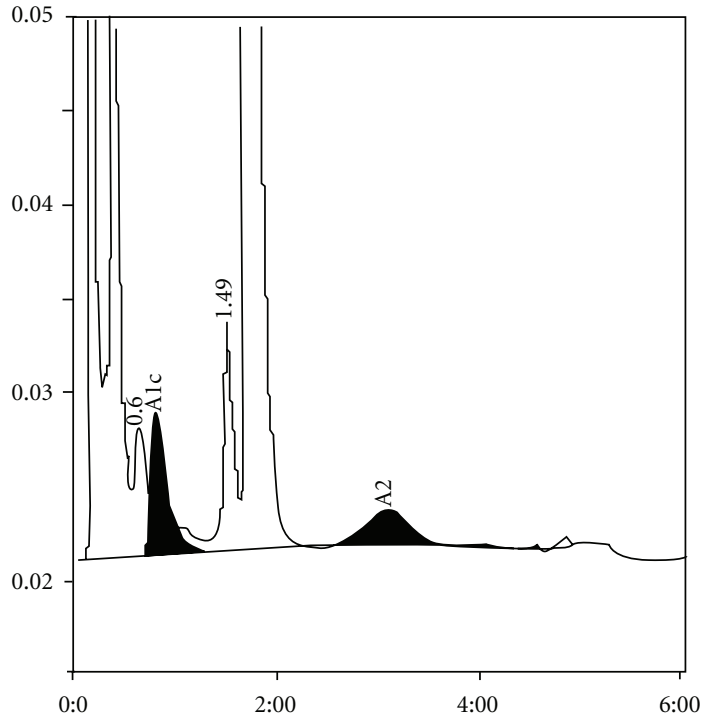

Figure 5: $\mathrm{HbH}$ with $\mathrm{HbA} 2$ of $1.1 \%$, elevated HbA1a, and an unknown peak at 0.38 minutes.

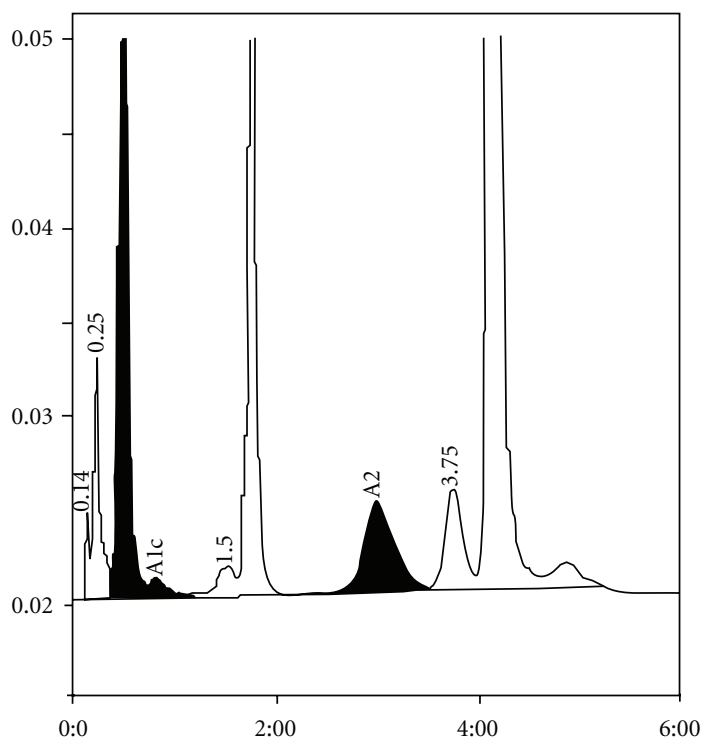

FIgURE 6: $\mathrm{HbS} \beta$-thalassemia with elevation of $\mathrm{HbF}$ and $\mathrm{HbA} 2$.

54.8), whereas it was contrary to the amount of $\mathrm{HbF}(19.2$ versus 31.3) (Table 3).

3.3. Homozygous Disorders (SS, EE). A lower average hemoglobin was seen in HbSS, whereas the percentage of abnormal hemoglobin was higher in $\mathrm{HbEE}$. The average $\mathrm{HbF}$ was, however, higher in HbSS (Table 4).

3.4. HbE Disorders (E Trait, EE, E $\beta$-Thalassemia). Comparing all the $\mathrm{HbE}$ disorders, it is seen that the lowest hemoglobin as well as the highest proportion of $\mathrm{HbF}$ is seen in $\mathrm{HbE} \beta$-thalassemia (Table 5). The single case of HbSE 
TABLE 2: Heterozygous hemoglobinopathies.

\begin{tabular}{lcccccccc}
\hline Disorder & No. of cases & $\mathrm{Hb} \mathrm{gm} \%$ & $\mathrm{MCV}(\mathrm{fl})$ & $\mathrm{MCH}(\mathrm{pg})$ & $\mathrm{MCHC}(\mathrm{g} / \mathrm{dL})$ & $\mathrm{RDW} \%$ & $\mathrm{RBC} \times 10^{6} / \mathrm{cumm}$ & $\mathrm{Abnor} \mathrm{Hb} \%$ \\
\hline E trait & 126 & 10.3 & 75.5 & 24.2 & 31.7 & 16.1 & 4.3 & 30.1 \\
S trait & 29 & 11.3 & 77.2 & 25.1 & 32.3 & 15.6 & 4.5 & 30.9 \\
D trait & 4 & 10 & 82.6 & 27.3 & 33 & 17.2 & 3.6 & 35.4 \\
\hline
\end{tabular}

TABle 3: Compound heterozygous disorders.

\begin{tabular}{|c|c|c|c|c|c|c|c|c|c|}
\hline Disorder & No. of cases & $\mathrm{Hb}(\mathrm{gm} \%)$ & $\mathrm{MCV}(\mathrm{fl})$ & $\mathrm{MCH}(\mathrm{pg})$ & $\mathrm{MCHC}(\mathrm{gm} / \mathrm{dL})$ & RDW (\%) & $\mathrm{RBC} \times 10^{6} \mathrm{cumm}$ & \%Abnor $\mathrm{Hb}$ & $\operatorname{HbF}(\%)$ \\
\hline$\overline{\mathrm{E} \beta} \beta$-thalassemia & 25 & 6.9 & 67.2 & 19.7 & 29.2 & 26.6 & 3.6 & 54.8 & 31.3 \\
\hline $\mathrm{S} \beta$-thalassemia & 14 & 9 & 73.8 & 22.8 & 30.7 & 18.9 & 4.1 & 65.6 & 19.2 \\
\hline
\end{tabular}

TABLE 4: Homozygous hemoglobinopathies.

\begin{tabular}{lccccccccc}
\hline Disorder & No. of cases & $\mathrm{Hb}(\mathrm{gm} \%)$ & $\mathrm{MCV}(\mathrm{fl})$ & $\mathrm{MCH}(\mathrm{pg})$ & $\mathrm{MCHC}(\mathrm{gm} / \mathrm{dL})$ & $\mathrm{RDW}(\%)$ & $\mathrm{RBC} \times 10^{6} \mathrm{cumm}$ & $\mathrm{Abnormal} \mathrm{Hb}$ & $\% \mathrm{HbF}$ \\
\hline HbEE & 103 & 9.8 & 63.6 & 20.4 & 31.9 & 18 & 4.8 & 90.8 & 3.7 \\
HbSS & 8 & 7.8 & 77.4 & 24.5 & 31.5 & 24.8 & 3.3 & 79.9 & 8 \\
\hline
\end{tabular}

TABle 5: HbE disorders.

\begin{tabular}{|c|c|c|c|c|c|c|c|c|c|}
\hline Disorder & No. of cases & $\mathrm{Hb}(\mathrm{gm} \%)$ & $\mathrm{MCV}(\mathrm{fL})$ & $\mathrm{MCH}(\mathrm{pg})$ & $\mathrm{MCHC}(\mathrm{gm} / \mathrm{dL})$ & RDW (\%) & $\mathrm{RBC} \times 10^{6}$ cumm & Abnormal $\mathrm{Hb} \%$ & $\% \mathrm{HbF}$ \\
\hline $\mathrm{HbE}$ trait & 126 & 10.3 & 75.5 & 24.2 & 31.7 & 16.1 & 4.3 & 30.1 & 1.32 \\
\hline $\mathrm{HbEE}$ & 103 & 9.8 & 63.6 & 20.4 & 31.9 & 18 & 4.8 & 90.8 & 3.7 \\
\hline $\operatorname{HbE} \beta$-thalassemia & 25 & 6.9 & 67.2 & 19.7 & 29.2 & 26.6 & 3.6 & 54.8 & 31.3 \\
\hline
\end{tabular}

disorder had a hemoglobin of $10.1 \mathrm{gm} \%$, thalassemic indices with $\mathrm{MCV}$ of $71 \mathrm{fl}, \mathrm{MCH}$ of $23.1 \mathrm{pg}, 36.7 \%$ of $\mathrm{HbA} 2+\mathrm{HbE}$, and $2.8 \%$ of $\mathrm{HbF}$.

3.5. Sickle Cell Disorders (S Trait, SS, S $\beta$-Thalassemia). Unlike the HbE disorders, homozygous HbS disorder had the lowest hemoglobin (Table 6). The single case of HbSC disorder had a hemoglobin of $13.8 \mathrm{gm} \%$ and $47.1 \% \mathrm{HbS}$, whereas $\mathrm{HbS}$ was $53.4 \%$ in HbSE disorder. The patients' $\mathrm{HbC}$ eluted in the $\mathrm{C}$ window at 4.79 minutes and constituted $45.8 \%$ of the total hemoglobin. These values of $\mathrm{HbS}$ are higher than seen in HbS trait where the average was 30.9\%.

The highest average $\mathrm{HbA} 2$ of $4.2 \%$ was seen in $\mathrm{HbS} \beta$ thalassemias (Table 7).

3.6. Thalassemias ( $\beta$-Thalassemia Trait, $\beta$-Thalassemia Major, $\alpha$-Thalassemia). On comparing the thalassemic disorders in our study ( $\beta$-thalassemia trait, $\beta$-thalassemia major, and $\alpha$-thalassemias), we observed that the lowest average hemoglobin was seen in $\beta$-thalassemia major. The lowest average MCV was seen, however, in $\beta$-thalassemia trait, whereas the lowest average $\mathrm{MCH}$ and $\mathrm{MCHC}$ was recorded in $\alpha$-thalassemias (Table 8 ). The average $\mathrm{HbF}$ was $88 \%$ in $\beta$-thalassemia major and less than one in $\alpha$-thalassemias ( $\mathrm{HbH})$.

All the cases of $\alpha$-thalassemias included in our study had numerous $\mathrm{HbH}$ inclusions. The single case of HbLepore trait had a hemoglobin of $6.6 \mathrm{gm} \%, \mathrm{MCV}$ of $52.9 \mathrm{fl}$, $\mathrm{MCH}$ of $15.8 \mathrm{pg}$, an elevated $\mathrm{HbF}$ of $13.7 \%$, and elevated $\mathrm{HbA} 2$ of $10.6 \%$. One case of hereditary persistence of fetal hemoglobin was noted with a hemoglobin of $13.3 \mathrm{gm} \%$, normal red cell indices, and an $\mathrm{HbF}$ of $36.2 \%$.

3.7. Minor Hemoglobins (Tables 9, 10, and 11). The highest mean HbAla was seen in $\alpha$-thalassemias and the lowest was noted in $\mathrm{HbD}$ trait. $\mathrm{HbE} \beta$-thalassemia had the highest mean $\mathrm{HbA} 1 \mathrm{~b}$ and the lowest was seen in homozygous $\mathrm{HbE}$ disorder. $\mathrm{HbA} 2$ was noted to be highest in $\beta$-thalassemia trait, and lowest in $\alpha$-thalassemias (excluding the $\mathrm{HbE}$ disorders where $\mathrm{HbE}$ and $\mathrm{HbA} 2$ fall in the same window and A2 is not detected separately).

3.8. Retention Times. All our cases of $\mathrm{HbH}$ in addition to having a high HbAla with a characteristic retention time of 0.16 minutes also had an unknown peak eluting at $0.37-$ 0.38 minutes. The average retention time of HbAla was 0.21 (range from 0.19 to 0.25 , except in $\alpha$-thalassemias where it was 0.16 minutes). The average retention time of $\mathrm{HbA} 1 \mathrm{~b}$ was 0.28 with a range from 0.25 to 0.35 , and $\mathrm{HbAlc}$ average was 0.79 , with a range of $0.71-0.97$ minutes. The retention time of $\mathrm{HbF}$ was 0.43 , ranging from 0.41 to 0.51 in all cases where $\mathrm{HbF}$ was normal or minimally elevated. In $\mathrm{HbE} \beta$ thalassemias, the average for HbF was 0.54 minutes, whereas in $\mathrm{HbS} \beta$-thalassemias it was 0.51 . The average retention time of P3 peak was 1.45 , with a range from 1.41 to 1.51 with the exception of the $\mathrm{HbJ}$ trait where it was 1.33 minutes. $\mathrm{HbA} 2$ retention time ranged from 2.74 to 3.09 with an average of 2.94. The average retention time of $\mathrm{HbA} 2$ in the $\mathrm{HbE}$ disorders was 2.76, 2.7, and 2.71 in $\mathrm{HbE}$ trait, $\mathrm{HbEE}$ disorder, and $\mathrm{HbE} \beta$-thalassemia, respectively. The retention time for 
TABLe 6: HbS disorders.

\begin{tabular}{lccccccccc}
\hline Disoder & No. of cases & $\mathrm{Hb}(\mathrm{gm} \%)$ & $\mathrm{MCV}(\mathrm{fl})$ & $\mathrm{MCH}(\mathrm{pg})$ & $\mathrm{MCHC}(\mathrm{gm} / \mathrm{dL})$ & $\mathrm{RDW}(\%)$ & $\mathrm{RBC} \times 10^{6} \mathrm{cumm}$ & Abnormal $\mathrm{Hb} \%$ & $\% \mathrm{HbF}$ \\
\hline HbS trait & 29 & 11.3 & 77.2 & 25.1 & 32.3 & 15.6 & 4.5 & 30.9 & 1.34 \\
HbSS & 8 & 7.8 & 77.4 & 24.5 & 31.5 & 24.8 & 3.3 & 79.9 & 8 \\
HbS $\beta$-thalassemia & 14 & 9 & 73.8 & 22.8 & 30.7 & 18.9 & 4.1 & 65.6 & 19.2 \\
\hline
\end{tabular}

TABLE 7: HbA2 in sickle cell disorders.

\begin{tabular}{lc}
\hline Disorder & A2 levels $(\%)$ \\
\hline HbS trait & 3.3 \\
HbSS & 2.7 \\
HbS $\beta$-thalassemia & 4.2 \\
\hline
\end{tabular}

$\mathrm{HbS}$ ranged from 4.04 to 4.18 in $\mathrm{HbS}$ trait with an average of 4.13. In HbSS disorder, the average was 4.08 and it was 4.10 in $\mathrm{HbS} \beta$-thalassemias. $\mathrm{HbD}$ had an average retention time of 3.75 with a range from 3.72 to 3.82 . In homozygous $\mathrm{HbD}$, the retention time of the abnormal hemoglobin was noted to be 3.77 minutes.

\section{Discussion}

In our study, the commonest disorder was $\beta$-thalassemia trait (37.9\%), followed by $\mathrm{HbE}$ trait $(23.2 \%)$, homozygous $\mathrm{HbE}$ (18.9\%), HbS trait (5.3\%), $\mathrm{HbE} \beta$-thalassemia (4.6\%), $\mathrm{HbS}$ $\beta$-thalassemia $(2.5 \%), \beta$-thalassemia major $(2.3 \%), \mathrm{HbH}$ $(1.6 \%)$, homozygous $\mathrm{HbS}(1.4 \%)$, and $\mathrm{HbD}$ trait $(0.7 \%)$. This compares with other studies $[8,9]$ (Table 12) where $\beta$-thalassemia trait is the commonest disorder. In the study by Balgir [10], sickle cell trait was noted to be common as the study included tribes from Orissa where this gene is prevalent. Our study had a high proportion of HbE disorders due to the many patients from north eastern regions of India who frequent our hospital for treatment.

The average value of $\mathrm{HbA} 2$ was $5.4 \%$ in $\beta$-thalassemia traits compared to $5 \%$ in other studies [5]. HbF was minimally elevated in $42 \%$ of our $\beta$-thalassemia trait patients and was around $1.4 \%$. HbF ranges from 10 to $90 \%$ in $\beta$ thalassemia major [5]. In our study, the $\mathrm{HbF}$ average was $88 \%$. HbA2 may be elevated in $\beta$-thalassemia major and in our study $15 \%$ of the patients with $\beta$-thalassemia major were seen to have elevated $\mathrm{HbA} 2$ and the average value of $\mathrm{HbA} 2$ was around 3.1\%.

In the Bio-Rad Variant analyser, $\mathrm{HbH}$ can only be suspected by the presence of peaks at the beginning of the chromatogram. In the D-10 analyser, we have seen that in addition to an elevation of HbAla with a characteristic retention time of 0.16 there was an unknown peak at 0.37 0.38 minutes. All our cases of $\mathrm{HbH}$ had low $\mathrm{HbA} 2$ with an average of $1.4 \%$, and numerous $\mathrm{HbH}$ inclusions.

$\mathrm{HbE}+\mathrm{A} 2$ has been reported to be around $30 \%$ in $\mathrm{HbE}$ trait [6]. In our study, the average was $30.1 \%$ with a minimal elevation of $\mathrm{HbF}$ of $1.32 \%$. $\mathrm{HbE}+\mathrm{A} 2$ has been reported to be around $90 \%$ with minimal elevation of $\mathrm{HbF}$ in homozygous $\mathrm{HbE}$, and it is about $40-60 \%$ in $\mathrm{HbE} \beta$-thalassemias [6].
In our study, $\mathrm{HbE}+\mathrm{A} 2$ was $90.8 \%$ in homozygous $\mathrm{HbE}$ and $54.8 \%$ in $\mathrm{HbE} \beta$-thalassemias. $\mathrm{HbF}$ was $3.7 \%$ in homozygous $\mathrm{HbE}$ and $31.3 \%$ in $\mathrm{HbE} \beta$-thalassemias.

HbS has been reported to be around $40 \%$ in trait, 90-95\% in homozygous $\mathrm{HbS}$, and less than $50 \%$ in $\mathrm{HbS}$ $\beta$-thalassemias [7]. In our cases, it was $30.9 \%$ in trait, $79.9 \%$ in the homozygous forms, and $65.6 \%$ in $\mathrm{HbS} \beta$ thalassemia. On comparing $\mathrm{HbE} \beta$-thalassemia and $\mathrm{HbS}$ $\beta$-thalassemia disorders, it is seen that the percentage of abnormal hemoglobin was more in $\mathrm{HbS} \beta$-thalassemia than $\mathrm{HbE} \beta$-thalassemias and the converse was seen for $\mathrm{HbF}$ (31.3 in $\mathrm{E}$ disorder and 19.2 in $\mathrm{S}$ disorder). However, the homozygous disorders of the same showed a higher abnormal hemoglobin in homozygous $\mathrm{HbE}(90.8 \%)$ with a lower average $\mathrm{HbF}(3.7 \%)$ when compared to homozygous HbS where it was $79.9 \%$ and $8 \%$, respectively. The lowest average hemoglobin among these four disorders was seen in homozygous $\mathrm{HbS}(7.8 \%)$. The reason for this could be that the sickle cell disorders are hemolytic disorders, whereas the $\mathrm{HbE}$ disorders are somewhat similar to thalassemic disorders (due to slower production), and hence in the homozygous form $\mathrm{HbS}$ is noted to have the lowest hemoglobin. It is interesting to note that among the $\mathrm{HbE}$ disorders $\mathrm{HbE} \beta$ thalassemia had the lowest hemoglobin and also the highest proportion of HbF. This does not reflect the clinical diversity of this disorder where highest $\mathrm{HbF}$ is noted in patients with a higher hemoglobin level. In all our cases of $\mathrm{HbE}$ disorders, the levels of $\mathrm{HbA} 2$ could not be evaluated as the presence of $\mathrm{HbE}$ is suspected by the presence of a abnormally high $\mathrm{HbA} 2$ peak. HbLepore, HbD-Iran, and others such as HbHonolulu also present as a raised $\mathrm{HbA} 2$ peak and the ethnicity along with the amount of abnormal hemoglobin is taken in to account before labeling these patients. HbLepore has been reported to have a characteristic hump in the HbA2 peak. However, in our patient it was not seen and the $\mathrm{HbA} 2$ was elevated to $10.6 \%$. The level of $\mathrm{HbD}$ has been reported to be less than $50 \%$ in traits, and in our cases the average was $35.4 \%$.

Levels of all the minor hemoglobins have not been reported in previous studies. Maximal elevation of minor hemoglobin $\mathrm{HbAla}$ (7.6) was seen in $\mathrm{HbH}$ and of $\mathrm{HbAlb}$ (6.5) was seen in $\mathrm{HbE} \beta$-thalassemia. The significance of this is not known. The retention times on the D-10 analyser have not been reported previously and to the best of our knowledge this is the first study detailing the retention times. After a detailed search, we have found only one large-scale study on the D-10 analyser [11], and to the best of our knowledge this is the first report from South India.

In addition to $\mathrm{HbA} 2$ being unrecordable in $\mathrm{HbE}$ disorders, the other drawback is the inability to measure HbAlc 
TABLE 8: Comparison of thalassemias (—indicates not detected).

\begin{tabular}{|c|c|c|c|c|c|c|c|c|c|}
\hline Disorder & No. of cases & $\mathrm{Hb}(\mathrm{gm} \%)$ & $\mathrm{MCV}(\mathrm{fl})$ & $\mathrm{MCH}(\mathrm{pg})$ & $\mathrm{MCHC}(\mathrm{gm} / \mathrm{dL})$ & RDW (\%) & $\mathrm{RBC} \times 10^{6} \mathrm{cumm}$ & $\mathrm{Hb}$ F\% & $\mathrm{Hb} \mathrm{A} \%$ \\
\hline$\beta$ thal trait & 206 & 10.4 & 65.5 & 19.9 & 30.5 & 16.5 & 5.2 & 1.4 & 81.3 \\
\hline$\beta$ thal major & 13 & 4.8 & 67.9 & 21.1 & 31 & 30.9 & 2.4 & 88 & 7.2 \\
\hline$\alpha$ thal & 9 & 8.3 & 67.2 & 18.4 & 28.2 & 23.3 & 4.5 & - & 77.4 \\
\hline
\end{tabular}

TABle 9: Minor hemoglobins in homozygous and compound heterozygous disorders (-indicates not detected).

\begin{tabular}{lcccc}
\hline Disorder & A1a & A1b & A1c & A2 \\
\hline Hb SS & 1.7 & - & 4.6 & 2.7 \\
Hb EE & 1.1 & 0.2 & 3.2 & 90.8 \\
Hb S $\beta$ thal & 3.4 & 3.8 & 5.5 & 4.2 \\
Hb E $\beta$ thal & 3.5 & 6.5 & 5.1 & 54.8 \\
\hline
\end{tabular}

TABle 10: Minor hemoglobins in heterozygous disorders.

\begin{tabular}{lcccc}
\hline Disorder & A1a & A1b & A1c & A2 \\
\hline Hb S trait & 0.9 & 1.03 & 5.4 & 3.3 \\
Hb E trait & 1.2 & 0.84 & 5.1 & 30.1 \\
Hb D trait & 0.3 & 0.97 & 4.6 & 3.12 \\
\hline
\end{tabular}

TABLE 11: Thalassemias and minor hemoglobins (-indicates not detected).

\begin{tabular}{lcccc}
\hline Disorder & A1a & A1b & A1c & A2 \\
\hline$\beta$ thal trait & 1.13 & 1.3 & 5.5 & 5.4 \\
$\beta$ thal major & - & - & - & 3.1 \\
$\alpha$ thal $(\mathrm{HbH})$ & 7.6 & 0.8 & 3.3 & 1.4 \\
\hline
\end{tabular}

TABLE 12: Comparison with other studies.

\begin{tabular}{lcccc}
\hline Study & Our & $\begin{array}{c}\text { Sachdev et al. } \\
{[8]}\end{array}$ & $\begin{array}{c}\text { Rao et al. } \\
{[9]}\end{array}$ & $\begin{array}{c}\text { Balgir } \\
{[10]}\end{array}$ \\
\hline$\beta$ thal trait & 37.9 & 8.9 & 18.1 & 18.2 \\
HbE trait & 23.2 & 0.19 & 1.1 & 0.9 \\
HbS trait & 5.3 & - & 1.4 & 29.8 \\
E $\beta$-thalassemia & 4.6 & 0.23 & 1.3 & 0.7 \\
S $\beta$-thalassemia & 2.5 & 0.07 & 0.8 & 1.7 \\
Hb SS & 1.4 & 0.03 & 0.5 & 7.5 \\
$\beta$-thalassemia major 2.3 & 0.6 & 2.9 & 5.3 \\
\hline
\end{tabular}

in presence of high $\mathrm{HbF}$ levels (15\% and more). The elevated $\mathrm{HbF}$ then presents as an elevated HbAlc or elevated LA1c (the labile portion of A1c) and other methods have be to used to evaluate the same.

\section{Acknowledgment}

The authors would like to acknowledge the efforts of Mr. Ayyal Raj E, Mr. Madhusudana Rao, and Ms. Kavitha M in carrying out the tests.

\section{References}

[1] R. S. Balgir, "Genetic epidemiology of the three predominant abnormal hemoglobins in India," Journal of Association of Physicians of India, vol. 44, no. 1, pp. 25-28, 1996.

[2] R. S. Balgir, "The spectrum of haemoglobin variants in two scheduled tribes of Sundargarh district in north-western Orissa, India," Annals of Human Biology, vol. 32, no. 5, pp. 560-573, 2005.

[3] M. Kamble and P. Chatruvedi, "Epidemiology of sickle cell disease in a rural hospital of Central India," Indian Pediatrics, vol. 37, no. 4, pp. 391-396, 2000.

[4] S. Agarwal, U. R. Gupta, N. Kohli, C. Verma, and S. S. Agarwal, "Prevalence of haemoglobin D in Uttar Pradesh," Indian Journal of Medical Research B, vol. 90, pp. 39-43, 1989.

[5] C. Borgna-Pignatti and R. Galanello, "Thalassemias and related disorders. Quantitative disorders of hemoglobin synthesis," in Wintrobes Clinical Hematology, J. P. Greer, J. Foerster, J. N. Lukens, G. M. Rodgers, F. Paraskevas, and B. Glader, Eds., pp. 1319-1365, Lippincott Williams and Wilkins, Philadelphia, Pa, USA, 11th edition, 2004.

[6] E. Vichinsky, "Hemoglobin e syndromes," Hematology, pp. 7983, 2007.

[7] B. J. Bain, "Sickle cell haemoglobin and its interactions with other variant haemoglobins and with thalassaemias," in Haemoglobinopathy Diagnosis, pp. 139-189, Blackwell, Oxford, UK, 2nd edition, 2006.

[8] R. Sachdev, A. R. Dam, and G. Tyagi, "Detection of Hb variants and hemoglobinopathies in Indian population using HPLC: report of 2600 cases," Indian Journal of Pathology and Microbiology, vol. 53, no. 1, pp. 57-62, 2010.

[9] S. Rao, R. Kar, S. K. Gupta, A. Chopra, and R. Saxena, "Spectrum of haemoglobinopathies diagnosed by cation exchangeHPLC \& modulating effects of nutritional deficiency anaemias from north India," Indian Journal of Medical Research, vol. 132, no. 11, pp. 513-519, 2010.

[10] R. S. Balgir, "Spectrum of hemoglobinopathies in the state of Orissa, India: a ten years cohort study," Journal of Association of Physicians of India, vol. 53, pp. 1021-1026, 2005.

[11] C. B. S. Dangi, M. Sajid, G. K. Sawke, and J. Ambhore, "Sickle cell hemoglobinopathies in district Bhopal," Indian Journal of Human Genetics, vol. 16, pp. 100-102, 2010. 


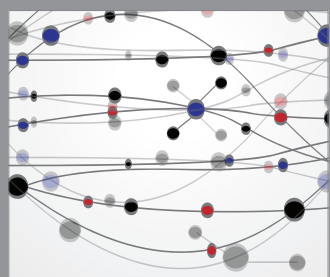

The Scientific World Journal
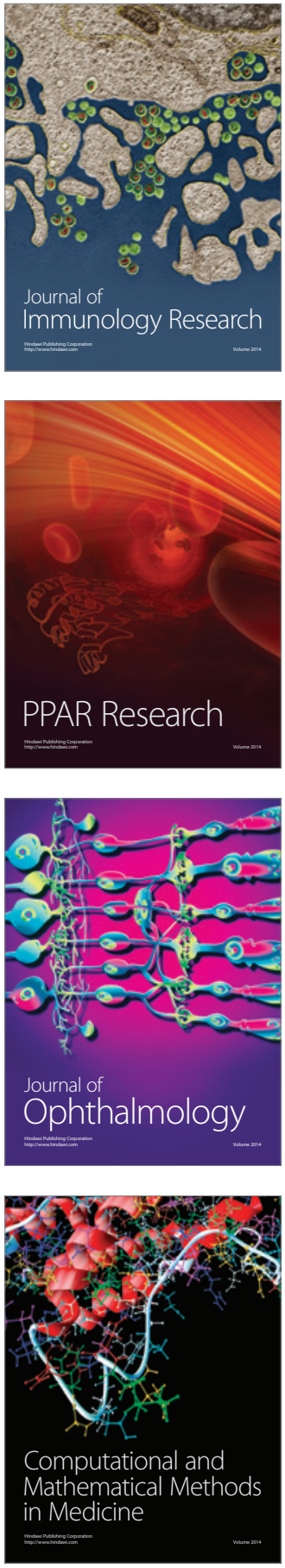

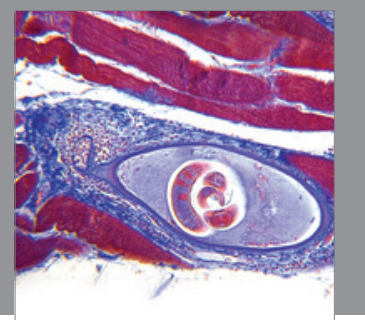

Gastroenterology

Research and Practice
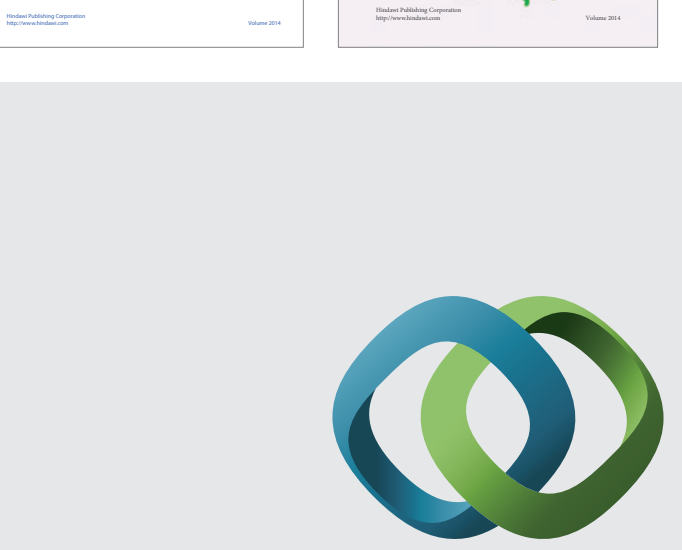

\section{Hindawi}

Submit your manuscripts at

http://www.hindawi.com
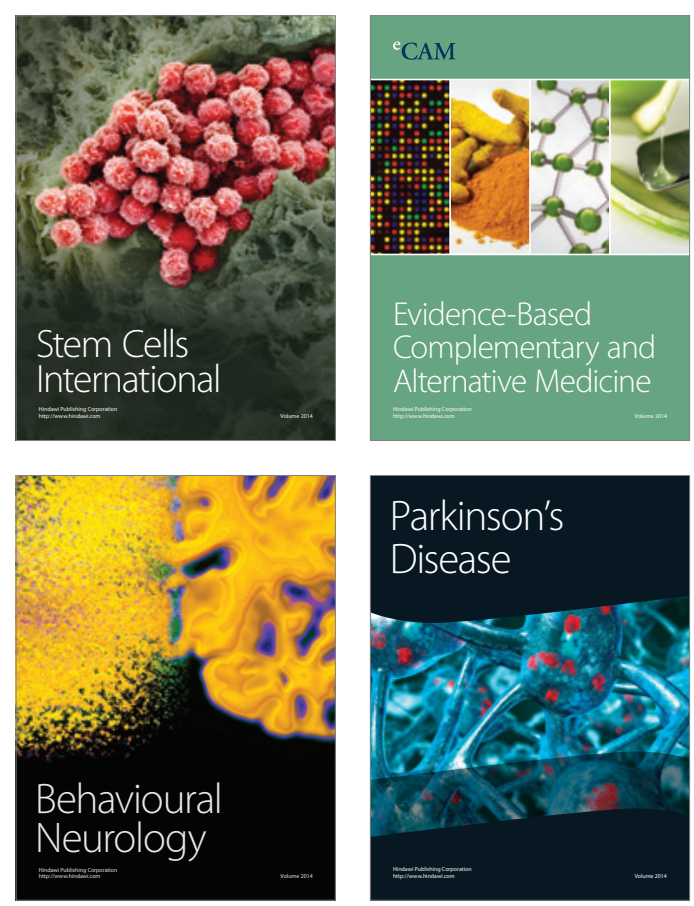

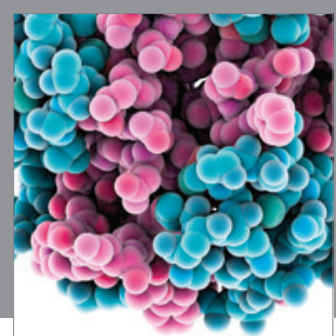

Journal of
Diabetes Research

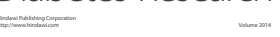

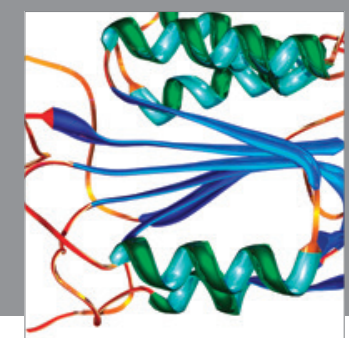

Disease Markers
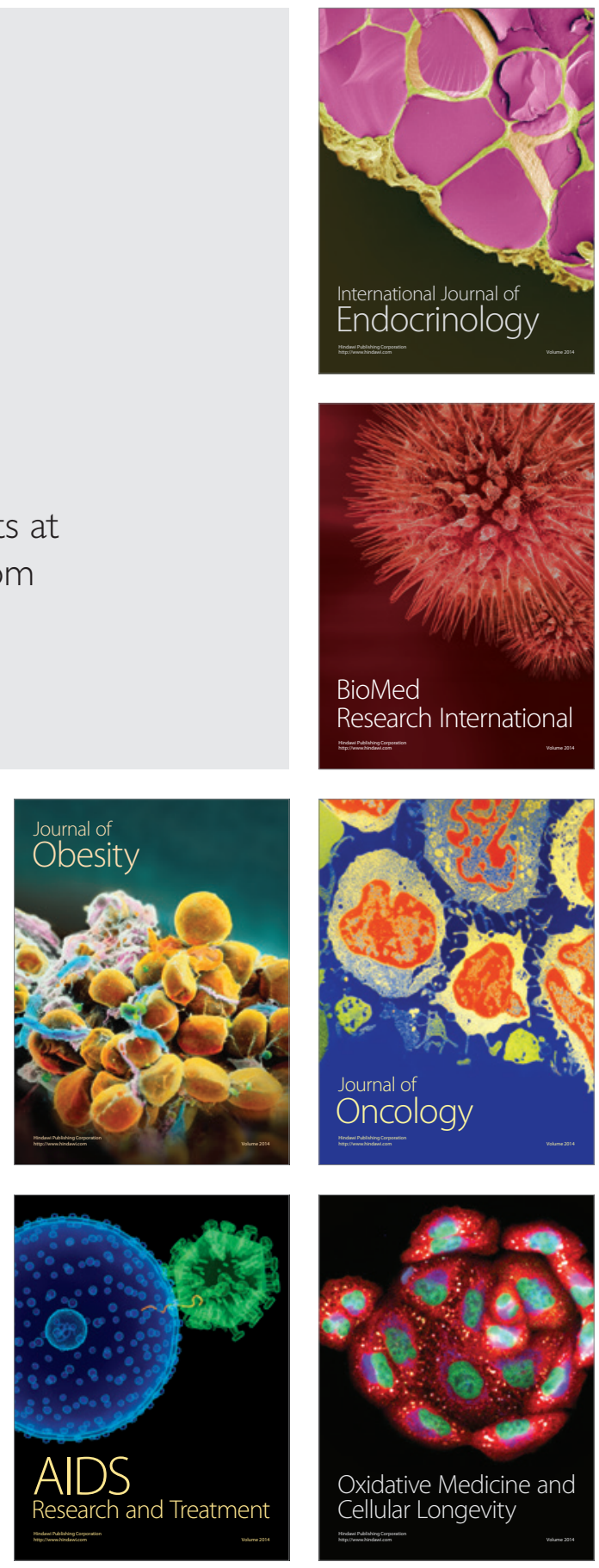